\title{
ANALISIS KEBUTUHAN PENGEMBANGAN MODEL PEMBELAJARAN BERBASIS ETNOSAINS UNTUK MENINGKATKAN KUALITAS PEMBELAJARAN IPA DAN MENANAMKAN NILAI KEARIFAN LOKAL SISWA SEKOLAH DASAR
}

\author{
Ratna Widyaningrum \\ Pendidikan Guru Sekolah Dasar Fakultas Keguruan dan Ilmu Pendidikan, \\ Universitas Slamet Riyadi \\ email: ratnawidya133@gmail.com
}

\begin{abstract}
Learning science-based local wisdom in the elementary school is one effort to instill the value of local wisdom in children from an early age. Teachers are also required to improve the quality of learning through a variety of innovations, one of them through ethnoscience. Ethnoscience raised the culture and local wisdom to serve as an object of learning science so that makes learning more meaningful. This study aims to analyze the needs of students in learning science in elementary school. The analysis is used in designing learning models that can combine science and local wisdom values through ethnosciences. The sampling technique was done by purposive sampling, with sample of 10 elementary school teachers in Banjarsari. Data were collected through literature study, documentation, and interview and analyzed descriptively. Based on the results of data analysis and discussion, it can be concluded as follows: 1) The teacher can determine the local culture and sort the material to be integrated in the learning of science based on local culture, 2) Learning resources that can be used in learning ethnoscience is the environment, literature, audio visual, and internet, and 3) Teachers can use a variety of methods in learning ethnosciences.

Keyword: Ethnoscience, Learning Quality, Local Wisdom.
\end{abstract}

\begin{abstract}
Abstrak
Pembelajaran sains berbasis kearifan lokal di SD merupakan salah satu upaya untuk menanamkan nilai kearifan lokal pada anak sejak dini. Guru juga dituntut untuk meningkatkan kualitas pembelajaran melalui berbagai macam inovasi salah satunya melalui etnosains. Etnosains mengangkat budaya dan kearifan lokal untuk dijadikan sebagai objek pembelajaran sains sehingga membuat pembelajaran lebih bermakna. Penelitian ini bertujuan untuk menganalisis kebutuhan siswa dalam belajar IPA di SD. Analisis tersebut digunakan dalam merancang model pembelajaran yang dapat memadukan antara sains dan nilai-nilai kearifan lokal melalui etnosains. Teknik pengambilan sampel dilakukan secara purposive sampling, dengan sampel sebanyak 10 orang guru Sekolah Dasar di Kecamatan Banjarsari. Data dikumpulkan melalui studi pustaka, dokumentasi, dan wawancara serta dianalisis secara deskriptif. Berdasarkan hasil analisis data dan pembahasan, dapat disimpulkan sebagai berikut: 1) Guru dapat menentukan budaya lokal dan memilah materi yang akan diintegrasikan dalam pembelajaran sains berbasis budaya lokal, 2) Sumber belajar yang yang dapat digunakan dalam pembelajaran etnosains adalah lingkungan sekitar, literatur, audio visual, dan internet, dan 3) Guru dapat menggunakan berbagai macam metode dalam pembelajaran etnosains

Kata kunci: Etnosains, Kualitas Pembelajaran, dan Kearifan Lokal
\end{abstract}

\section{PENDAHULUAN}

Kurikulum 2013 merupakan kurikulum yang menekankan pembelajaran secara interaktif, inspiratif, menyenangkan serta menantang. Hal tersebut akan memacu siswa lebih termotivasi dalam pembelajaran dan berpartisipasi secara aktif. Selain itu, siswa diberikan ruang yang 
cukup untuk mengembangkan kreativitas dan kemandirian sesuai dengan bakat, minat, dan perkembangan fisik. Sekolah Dasar merupakan salah satu lembaga formal yang telah menerapkan pembelajaran Kurikulum 2013 secara bertahap.

Adanya kurikulum baru di sekolah menuntut guru untuk lebih kreatif dalam mengajar. Oleh karena itu, guru harus mampu memberikan inovasi- inovasi dalam pembelajaran. Kehadiran inovasi pembelajaran sangat diperlukan sehingga pembelajaran menjadi lebih menyenangkan. Salah satu pembelajaran yang perlu mendapat perhatian adalah pembelajaran IPA.

Di Sekolah Dasar (SD), pembelajaran IPA terintegrasi dalam suatu tema. Menurut Arlianovita dkk. (2015: 1) IPA merupakan kesatuan produk, proses, dan sikap ilmiah. Pembelajaran IPA dapat menjadi sarana bagi siswa untuk mempelajari tentang diri sendiri serta alam sekitar serta menerapkan dalam kehidupa sehari-hari.

Namun, ditemukan beberapa kelemahan siswa di Indonesia, khususnya dalam pembelajaran sains. Berdasarkan hasil Trends in International Mathematics and Science Study (TIMSS) 2015, siswa di Indonesia menguasai soal-soal yang bersifat rutin, komputasi sederhana, serta mengukur pengetahuan akan fakta yang berkonteks keseharian. Siswa Indonesia perlu penguatan kemampuan mengintegrasikan informasi, menarik simpulan, serta menggeneralisir pengetahuan yang dimiliki ke hal-hal yang lain.

Survei tersebut diperkuat dengan adanaya temuan dari Programme for Economic Co-operation and Development (PISA) yang diriis pada tahun 2016, menyebutkan bahwa performa siswa-siswi Indonesia dalam hal matematika dan sains masih tergolong rendah. Rata-rata pencapaian skor untuk sains, literasi, dan matematika berada di peringkat 62,61 , dan 63 dari 69 negara yang dievaluasi. Selain itu, pada abad XXI, literasi dasar (Sains, Matematika, membaca, dan teknologi) harus dikuasai dan dimiliki oleh siswa. Demikian pula dengan kecakapan berpikir kritis, kreatif, komunikasi, kolaborasi, dan karakter. Berdasarkan temuan tersebut maka diperlukan penguatan pembelajaran dalam bidang IPA di Sekolah Dasar.

Salah satunya upaya yang dapat ditempuh adalah dengan mengembangkan model-model pembelajaran yang sesuai dengan kurikulum dan karakteristik siswa. Etnosains merupakan salah satu terobosan baru dalam dunia pendidikan. Menurut Battiste (2005) dalam Indrawati dan Qosyim (2017: 1) etnosains merupakan suatu kajian dari budaya masyarakat dan fenomena yang berhubungan dengan alam yang terdapat di dalam masyarakat. Etnosains bersifat turun temurun dan merupakan pengetahuan-pengetahuan asli masyarakat.

Menurut Prasetyo (2013) keunggulan lokal merupakan ciri khas daerah yang mencakup aspek ekonomi, budaya, teknologi informasi dan komunikasi dan ekologi yang dikembangkan dari potensi daerah. Aspek potensi pengembangan keunggulan lokal meliputi SDA, SDM, Geografis, Budaya dan Historis. Pendidikan Berbasis Keunggulan Lokal merupakan usaha sadar yang terencana melalui penggalian dan pemanfaatan potensi daerah setempat secara arif dalam upaya mewujudkan suasana belajar dan proses pembelajaran, agar peserta didik aktif mengembangkan potensi dirinya untuk memiliki keahlian, pengetahuan dan sikap dalam upaya ikut serta membangun bangsa dan Negara.

Aji (2017: 8) mengemukakan bahwa struktur kurikulum di SD harus bersifat holistik berbasis sains (alam, sosial, dan budaya). Melalui pembelajaran etnosains siswa dapat melakukan observasi secara langsung sehingga akan memudahkan siswa dalam mengidentifikasi, menjelaskan fenomena secara ilmiah, serta menyimpulkan. Pengetahuan budaya tidak hanya berkaitan dengan kearifan lokal, 
tetapi juga mengenai filosofi kehidupan bermasyarakat. Hal tersebut akan berdampak pada penananaman nilai-nilai budaya serta pembentukan karakter pada diri siswa.

Pembelajaran etnosains relevan dengan landasan filosofi pengembangan kurikulum 2013, yaitu: 1) pendidikan berakar pada budaya bangsa untuk membangun kehidupan bangsa pada masa kini dan masa mendatang; 2) siswa adalah pewaris budaya bangsa yang kreatif; 3) pendidikan ditujukan untuk mengembangkan kecerdasan intelektual dan kecemerlangan akademik melalui pendidikan disiplin ilmu; 4) pendidikan untuk membangun kehidupan masa kini dan masa depan yang lebih baik dari masa lalu dengan berbagai kemampuan intelektual, kemampuan berkomunikasi, sikap sosial, kepedulian, dan berpartisipasi untuk membangun kehidupan masyarakat dan bangsa yang lebih baik. Keberhasilan proses pembelajaran di sekolah sangat dipengaruhi oleh latar belakang budaya yang dimiliki oleh siswa atau masyarakat dimana sekolah itu berada. Hal tersebut tentunya akan berpengaruh pada kualitas pembelajaran IPA.

Kualitas pembelajaran adalah intensitas keterkaitan antara guru, siswa, materi, iklim pembelajaran, dan media dalam menghasilkan proses dan hasil belajar yang optimal sesuai dengan tujuan pembelajaran. Secara kasat mata indikator kualitas pembelajaran dapat dilihat antara lain dari perilaku pembelajaran guru (teacher behavior), perilaku dan dampak belajar siswa (student behavior), iklim pembelajaran (learning climate), materi pembelajaran, dan media pembelajaran.

Masing-masing indikator tersebut secara singkat dapat dijabarkan sebagai berikut: 1) aspek guru, kualitas dapat dilihat dari seberapa optimal guru mampu memfasilitasi proses belajar siswa; 2) aspek siswa, kualitas dapat dilihat perilaku dan dampak belajar siswa yang mampu membuat siswa termotivasi, aktif, dan kreatif; 3) aspek iklim pembelajaran, kualitas dapat dilihat dari seberapa besar suasana belajar mendukung terciptanya kegiatan pembelajaran yang menarik, menantang, menyenangkan dan bermakna bagi siswa; 4) aspek media belajar, kualitas dapat dilihat dari seberapa efektif media belajar digunakan oleh guru untuk meningkatkan intensitas belajar siswa; 5) aspek materi, kualitas dapat dilihat dari kesesuaiannya dengan tujuan dan kompetensi yang harus dikuasai siswa (Haryati dan Rochman, 2012).

Selain itu, pembelajaran IPA dengan menggunakan pendekatan etnosains membuat siswa lebih peduli terhadap lingkungan sosial dan budaya, serta dapat menanamkan nila-nilai karakter budaya lokal. Pembelajaran berbasis budaya merupakan suatu model pendekatan pembelajaran yang lebih mengutamakan aktivitas siswa dengan berbagai latar belakang budaya yang dimiliki (Sardjiyo Paulina Pannen dalam Supriyadi, 2011:3). Model pembelajaran berbasis budaya penting untuk diterapkan karena pembelajaran di sekolah dasar tidak hanya bertujuan untuk siswa namun juga menekankan pada pembentukan nilai-nilai karakter budaya bangsa.

Berdasarkan latar belakang tersebut, maka penelitian yang berjudul etnosains sebagai upaya meningkatkan kualitas pembelajaran IPA dan menanamkan nilai karakter di Sekolah Dasar penting untuk dilakukan, sebagai kajian awal dalam mengembangkan suatu model pembelajaran berbasis etnosains di Sekolah Dasar.

Rumusan masalah dalam penelitian ini adalah: 1) Bagaimanakah langkah guru dalam memetakan materi IPA yang akan digunakan dalam pembelajaran berbasis etnosains?, 2) Bagaimanakah langkah pemilihan sumber belajar dalam pembelajaran IPA berbasis etnosains?, dan 3) Bagaimanakah langkah guru dalam menentukan metode yang digunakan dalam pembelajaran IPA berbasis etnosains?

Adapun tujuan penelitian ini adalah untuk memperoleh data awal dan draf 
tentang produk model pembelajaran IPA berbasis etnosains. Namun secara khusus tujuan penelitian ini adalah: 1) Memetakan materi IPA di SD khususnya kelas 3 dan 5 untuk diintegrasikan dengan budaya lokal di Surakarta, 2) Merumuskan sumber belajar yang akan digunakan dalam pembelajaran IPA berbasis etnosains, 3) Merumuskan metode yang akan digunakan dalam pengembangan model pembelajaran IPA berbasis etnosains.

\section{METODE PENELITIAN}

Penelitian ini merupakan penelitian tahap awal pengembangan, sehingga rancangan penelitian ini adalah rancangan pengembangan. Penelitian ini hanya terbatas pada analisis kebutuhan (need assessment) dalam rangka untuk mengetahui analisis awal pengembangan model pembelajaran IPA berbasis kearifan lokal melalui pendekatan pembelajaran etnosains. Lokasi pada penelitian ini adalah Sekolah Dasar di Kecamatan Banjarsari, Surakarta. Sekolah Dasar di Kecamatan Banjarsari memiliki hetrogenitas dan lingkungan belajar yang berbeda, namun budaya lokal yang ditanamkan adalah budaya lokal Surakarta. Hal tersebut menjadi pertimbangkan dalam menentukan sampel penelitian sebagai tempat uji coba nanti. Sampel penelitian ini adalah guru kelas 3 dan kelas 5 yaitu sebanyak 10 orang guru, sampel diambil dengan teknik purposive sampling. Teknik pengumpulan data dalam penelitian ini teknik pengumpulan data yang digunakan adalah studi pustaka, dokumentasi, dan wawancara. Data penelitian ini berupa data kualitatif. Oleh karena itu pengolahan datanya menggunakan metode deskriptif kualitatif.

\section{HASIL DAN PEMBAHASAN}

Berdasarkan hasil wawancara dengan guru di Sekolah Dasar, kearifan lokal yang ada di Surakarta sangat bervariasi, mulai dari segi gagasan/pemikiran, pengetahuan atau

pandangan, nilai-nilai norma sosial, bangunan atau artefak yang memiliki nilai simbolis, budaya, bahasa, produk lokal dan masih banyak lagi. Oleh karena itu, diperlukan pembatasan berkenaan dengan keraifan lokal yang akan diintegrasikan dengan pembelajaran IPA. Kearifan lokal yang paling umum di kenal oleh siswa antara lain adalah: Batik Laweyan, Pasar Gede, tanaman obat sebagai bahan pembuatan jamu tradisonal, dan sistem bercocok tanam pada masyarakat.

Hal tersebut sesuai dengan yang dikemukakan oleh Wagiran (2012: 4-5) bahwa kearifan lokal merupakan fenomen yang luas dan komprehensif. Cakupan kearifan lokal meliputi: 1) pemikiran, sikap, dan tindakan berbahasa, berolah seni, dan bersastra; 2) pemikiran, sikap, dan tindakan dalam berbagai artefak budaya; 3) pemikiran, tindakan sosial bermasyarakat. Kategorisasi kearifan lokal menurut Sungri (2008) dalam Wagiran (2012: 332) meliputi: pertanian, kerajinan tangan, pengobatan herbal, pengelolaan sumber daya alam dan lingkungan, perdagangan, seni budaya, bahasa daerah, filosofi, agama dan budaya serta makanan tradisonal.

Berdasarkan pemetaan materi pada kelas III dan V, maka diperoleh hasil sebagai berikut: 
Tabel 1. Pemetaan Materi Pembelajaran IPA

\begin{tabular}{lll}
\hline No. & Kearifan Lokal & Materi Pembelajaran \\
\hline 1. & Batik Laweyan & $\begin{array}{l}\text { Pencemaran lingkungan yang mempengaruhi } \\
\text { kualitas air dan cara pengolahan limbah sisa } \\
\text { pembuatan batik. } \\
\text { (Materi kelas 5 tema 8) }\end{array}$ \\
& & $\begin{array}{l}\text { Makanan dan kesehatan } \\
\text { (Materi Kelas 5 Tema 3) }\end{array}$ \\
2. $\quad$ Pasar Gede & $\begin{array}{l}\text { Perkembang biakan pada tumbuhan } \\
\text { (Materi kelas 3 Tema 1 subtema 2) }\end{array}$ \\
3. $\quad$ Tanaman obat sebagai bahan & Perubahan musim (Materi kelas 3 Tema 3 \\
4. $\quad \begin{array}{l}\text { Sistem bercocok tanam } \\
\text { masyarakat jawa }\end{array}$ & $\begin{array}{l}\text { Subtema 3) dan ekosistem } \\
\text { (Materi Kelas 5 Tema 5) }\end{array}$ \\
\hline
\end{tabular}

Berdasarkan Tabel 1. Maka dapat dijelaskan bahwa pemetaan materi kelas III ada pada tema 1 dan 3, sedangkan pada kelas $\mathrm{V}$ ada pada tema 3, 5, dan 8. Menurut guruguru integrasi kearifan lokal dapat dilakukan secara terbuka yang disisipkan ke dalam tema-tema tersebut, atau juga dapat dikemas dalam bentuk pesan tersembunyi (hidden curriculum) yaitu dengan penanaman norma, kebiasaan baik, dan prinsip bersosial.

Hal tersebut sesuai dengan penelitian yang dilakukan oleh Wagiran (2010: 19) agar tidak merubah pembelajaran yang ada pada kurikulum serta mata pelajaran yang berlaku, maka perlu ditemukan cara mengintegrasikan nilai-nilai kearifan lokal dalam pembelajaran. Guru perlu melakukan identifikasi kearifan lokal yang dapat dikembangkan bersama pembahasan pokok bahasan tertentu. Jika identifikasi telah dilakukan untuk semua pokok bahasan, selanjutnya guru mengintegrasikan nilainilai kearifan lokal tersebut dalam rancangan pembelajaran. Nilai-nilai tersebut dimasukkan menjadi bagian dari Rencana Pelaksanaan Pembelajaran (RPP) mata pelajaran terkait. Jika semua guru atau semua mata pelajaran telah melakukan identifikasi, sekolah (melalui pertemuan guru) dapat melakukan identifikasi kontribusi masing-masing mata pelajaran dalam menanamkan kearifan lokal. Hal tersebut diperlukan agar sekolah dapat merencanakan integrasi kearifan lokal tersebut secara seimbang.

Selain itu, pemilihan media dalam mengimplementasikan pembelajaran IPA berbasis etnosains perlu memperhatikan pemilihan media. Berdasarkan hasil wawancara dan dokumentasi didapatkan bahwa ada beberapa sumber belajar yang efektif digunakan dalam pembelajaran IPA, antara lain lingkungan sekitar, literatur, audio visual, dan internet.

Sumber belajar mencakup semua hal yang dapat digunakan untuk membantu seorang guru dalam belajar, mengajar dan menampilkan kompetensinya. Pada kenyataan di lapangan, belum banyak variasi sumber belajar yang dimanfaatkan secara optimal. Sebagian besar guru cenderung memanfaatkan buku teks sebagai satu-satunya sumber belajar. Oleh sebab itu, guru harus mengembangkan dan merancang sumber belajar secara sistematis berdasarkan kebutuhan kegiatan pembelajaran yang akan dilaksanakan dan juga berdasarkan pada karakteristik para siswa yang akan mengikuti kegiatan pembelajaran tersebut.

Menurut Dick dan Carey (2005: 27) mengatakan bahwa kriteria pemilihan sumber belajar, yaitu: 1) Disesuaikan dengan tujuan pembelajaran; 2) Ketersediaan sumber setempat, artinya jika sumber belajar yang bersangkutan tidak terdapat pada sumber- sumber yang ada maka sebaiknya dibeli atau dirancang atau dibuat sendiri; 3) Ketersersediaan dana, tenaga, dan fasilitas yang cukup untuk mengadakan sumber belajar tersebut; 4) Keluwesan, kepraktisan, dan ketahanan sumber belajar yang bersangkutan untuk 
jangka waktu yang relatif lama; dan 5) Efektifitas biaya dalam jangka waktu yang relatif lama.

Pembelajaan IPA dengan menggunakan pendekatan etnosains mengkaji budaya yang ada di lingkungan siswa, sehingga hal tersebut dijumpai oleh siswa dan diharapkan siswa lebih mudah memahami materi serta membuat pebelajaran lebih bermakna. Guru dapat membuat suatu media berupa video, handout, modul, komik, dan lainnya untuk mempermudah pelaksaanaan pembelajaran IPA berbasis etnosains. Selain itu, guru dapat memanfaatkan berbagai literatur serta internet untuk membantu proses pembelajaran.

Selain pemilihan sumber belajar, hal yang tidak kalah penting adalah pemilihan metode dalam pembelajaran. Berdasarkan hasil wawancara didapatkan bahwa biasanya guru-guru di Sekolah Dasar mengajar dengan metode ceramah bervariasi dan penugasan. Namun, sebenarnya ada beberapa metode lain yang dapat digunakan untuk mendukung pembelajaran IPA berbasis etnosains, antara lain adalah observasi, demonstrasi, diskusi, proyek, eksperimen, dan karya wisata.

Hal tersebut sesuai dengan penelitian yang dilakukan oleh Arlianovita dkk. (2015: 103) yang mengemukakan bahwa observasi bertujuan untuk mengajak siswa mengenal objek/gejala/masalah, menelaah permasalahan, kemudian menyimpulkan atas konsep yang dipelajarinya. Konseptualisasi dan pemahaman yang diperoleh siswa tidak secara langsung dari guru, namun diperoleh melalui kegiatan ilmiah. Adanya eksplorasi dan observasi terhadap lingkungan, siswa akan berinteraksi dengan fakta yang ada di lingkungan sehingga menemukan pengalaman dan sesuatu yang menimbulkan pertanyaan atau masalah. Lingkungan yang dimaksud tidak hanya lingkungan fisik saja, tetapi juga meliputi lingkungan sosial, budaya, dan teknologi.

Hal tersebut diperkuat dengan pendapat dari Wagiran (2010: 20) yang mengemukakan bahwa integrasi kearifan lokal tidak harus selalu dilakukan melalui materi pembelajaran, tetapi dapat pula dilakukan melalui berbagai cara seperti strategi pembelajaran, media pembelajaran, sumber belajar, ataupun evaluasi pembelajaran. Setelah guru menentukan kearifan lokal yang akan ditanamkan, maka guru dapat memilih salahsatu atau beberapa cara mengintegrasikan kearifan lokal tersebut. Cara tersebut antara lain melalui strategi pembelajaran, metode pembelajaan, media pembelajaran, bahan ajar ataupun evaluasi pembelajaran.

Menurut Samiudin (2016: 119-121) terdapat faktor-faktor yang mempengaruhi pemilihan metode pembelajaran, yaitu: 1) strategi yang tepat; 2) efektifitas penggunaan metode; 3) tujuan pembelajaran. Selain itu, Hamdayana (2008: 95) mengemukakan bahwa dalam memilih metode guru harus memperhatikan tujuan pembelajaran yang hendak dicapai, karakteristik siswa, bahan ajar, situasi belajar mengajar, fasilitas yang tersedia, kemampuan atau kompetensi guru, serta analisis terhadap kelebihan dan kekurangan metode.

Rentang usia siswa SD terletak antara 7 sampai dengan 13 tahun. Menurut Piaget dalam Prastowo (2014:6) siswa SD berada pada fase operasional konkret. Berdasarkan fase ini, pembelajaran di SD hendaknya diawali dengan sesuatu yang konkret dan nyata serta dekat dengan kehidupan, pengetahuan dan pengalaman siswa. Pemilihan kearifan lokal dalam mata pelajaran IPA sebagai tema utama dikarenakan tema tersebut berhubungan erat dengan kehidupan sehari-hari dan dapat menanamkan nilai-nilai karakter pada siswa. Selain itu, implementasi model pembelajaran yang tepat pastinya akan berpengaruh pada peningkatan kualitas pembelajaran di sekolah.

Hal tersebut sesuai dengan penelitian Atmojoyo (2018: 5) yang mengemukakan bahwa pembelajaran IPA terpadu berpendekatan etnosains terbukti efektif mampu memperbaiki kualitas pembelajaran 
pada aspek aktivitas dan hasil belajar kognitif siswa.

\section{SIMPULAN}

Berdasarkan hasil analisis data dan pembahasan, dapat disimpulkan sebagai berikut: 1) Guru dapat menentukan budaya lokal dan memilah materi yang akan diintegrasikan dalam pembelajaran sains berbasis budaya lokal, 2) Sumber belajar yang yang dapat digunakan dalam pembelajaran etnosains adalah lingkungan sekitar, literatur, audio visual, dan internet, dan 3) Guru dapat menggunakan berbagai macam metode dalam pembelajaran etnosains.

Adanya keterpaduan tersebut

Adanya studi pendahuluan untuk menganalisis tentang cara meningkatkan pemahaman nilai kearifan lokal dan kualitas pembelajaran melalui etnosains, maka diperlukan penelitian lebih lanjut tentang desain pengembangan model pembelajaran yang berbasis etnosains untuk membelajarkan IPA di Sekolah Dasar.

\section{DAFTAR PUSTAKA}

Aji, S. D. 2017. Etnosains dalam Membentuk Kemampuan Berpikir Kritis dan Kerja Ilmiah Siswa. Prosiding Seminar Nasional Pendidikan Fisika III 2017. Universitas PGRI Madiun. 15 Juli 2017. 7-11.

Prastowo, A. 2014. Pemenuhan Kebutuhan Psikologis Peserta Didik SD/MI melalui Pembelajaran Teamtik Terpadu. Jurnal Pendidikan Sekolah Dasar. 1(1).1-13.

Arlianovita, D., Setiawan, B., dan Sudibyo, E. 2015. Pendekatan Etnosains dalam Proses Pembuatan Tempe terhadap Keampuan Literasi Sains. Prosiding Seminar Nasional Fisika dan Pembelajarannya 2015. Universitas Negeri Malang.

Atmojoyo, SE. 2018. Pengembangan Perangkat Pembelajaran IPA Terpadu Berpendekatan Etnosains. Jurnal Pendidikan Sains (JPS). 5(2). 5-13.

Dick, W. \& Carey, JO. 2005. The Systematic Design of Instruction. Boston: Longman.

Hamdayana, J. 2008. Metodologi Pengajaran. Jakarta: Kalam Mulia.

Haryati, T dan Rochman, N. 2012. Peningkatan Kulaitas Pembelajaran Pendidikan Kewarganegaraan Melalui Praktik Belajar Kewarganegaraan (Project Citizen). Jurnal Ilmiah CIVIS. 2(2).

Indrawati, M dan Qosyim, A. 2017. Keefektifan Lembar Kerja Siswa (LKS) Berbasis Etnosains pada Materi Bioteknologi untuk Melatihkan Keterampilan Proses Sains Siswa Kelas IX. E-journal UNESA. 152-158.

Prasetyo, ZK. 2013. Pembelajaran Sains Berbasis Kearifan Lokal. Seminar Nasional Fisika dan Pendidikan Fisika. Surakarta, 14 September 2013.

Samiudin. 2016. Peran Metode untuk Mencapai Tujuan Pembelajaran. Jurnal Studi Islam. 2(2). 113-131.

Supriyadi. 2011. Pembelajaran Etnomatematika Dengan Media Lidi Dalam Operasi Perkalian Matematika untuk Meningkatkan Karakter Kreatif Dan Cinta Budaya Lokal Mahasiswa PGSD. Prosiding Seminar Nasional STKIP Siliwangi.1-8.

Wagiran. 2010. Pengembangan Model Pendidikan Kearifan Lokal dalam Mendukung Pembangunan Provinsi Daerah Istimewa Yogyakarta 2020. (Tahun Kedua). Jurnal Penelitian dan Pengembangan. 3(3). 1-29.

. 2012. Pengembangan Karakter Berbasis Kearifan Lokal Hmemayu Hayuning Bawana. Jurnal Pendidikan Karakter. Tahun ke 2, No. 3. 329-339. 